\title{
A new long-finned Corydoras Lacépède, 1803 (Siluriformes: Callichthyidae) from the lower rio Paraná basin, Brazil
}

\author{
Luiz F. C. Tencatt ${ }^{1}$, Marcelo R. Britto ${ }^{2}$ and Carla S. Pavanelli ${ }^{1}$
}

A new species of Corydoras is described from the lower rio Paraná basin, just downstream from Itaipu Dam, Brazil, close to Paraguay boundary. The new species can be distinguished from most of its congeners by the infraorbital 2 with a posterior laminar expansion conspicuously reduced, first and second dorsal-fin branched rays conspicuously elongated in males, mesethmoid entirely covered by skin, and by the presence of four to six irregular black or brownish blotches on the midline of the flank. The probable occurrence of the new species in the floodplain of the upper portion of the rio Paraná drainage is discussed.

Uma espécie nova de Corydoras é descrita da bacia do baixo rio Paraná, logo a jusante da barragem de Itaipu, Brasil, próximo a fronteira com o Paraguai. A espécie nova pode ser distinguida da maioria de suas congêneres pelo infraorbital 2 com uma expansão laminar posterior conspicuamente reduzida, primeiro e segundo raios ramificados da nadadeira dorsal conspicuamente alongados nos machos, mesetmoide totalmente coberto por pele e presença de quatro a seis manchas pretas ou amarronzadas irregulares na linha mediana do flanco. Discute-se a provável ocorrência da espécie nova na planície de inundação da bacia da porção superior do rio Paraná.

Key words: Canal da Piracema, Corydoradinae, Itaipu dam, Sexual dimorphism, Taxonomy.

\section{Introduction}

Callichthyidae is composed of catfishes having the flanks covered by two longitudinal series of dermal plates and currently comprises about 200 species (Reis, 2003; Eschmeyer, 2013). Corydoras Lacépède harbors about 170 species, being the most species-rich genus of Siluriformes (Eschmeyer, 2013). Gosline (1940) performed the first comprehensive study including Corydoras species in his revision of the Callichthyidae. Thirty years later, Nijssen (1970) carried out a review of the Corydoras species from Suriname and additionally allocated them, with exception of four species, in nine groups based mainly in color pattern and some morphometric features. Subsequently, Nijssen \& Isbrücker (1980) revised Corydoras, allocating the hitherto 94 known species in five groups. Phylogenetic studies that included species of Corydoras were also advanced, primarily by Britto (2003) and more recently by Alexandrou et al. (2011).

The rio Paraná is the second longest river in South
America, being primarily separated in two ichthyofaunistic provinces, the upper portion of rio Paraná drainage and the Parano-Platense drainage, previously separated by the “cachoeira de Sete Quedas" (Bonetto, 1986). Currently, after submersion of the "cachoeira de Sete Quedas", the barrier between these two provinces was replaced by the Itaipu dam. Twelve nominal species of Corydoras, namely: C. aeneus (Gill), C. carlae Nijssen \& Isbrücker, C. difluviatilis Britto \& Castro, C. diphyes Axenrot \& Kullander, C. ehrhardti Steindachner, C. flaveolus Ihering, C. gladysae Calviño \& Alonso, C. longipinnis Knaack, $C$. micracanthus Regan, C. paleatus (Jenyns), C. petracinii Calviño \& Alonso and C. undulatus Regan, have been reported in the rio Paraná basin. Recent examination of specimens from the rio Paraná basin collected near the Itaipu dam revealed the presence of an undescribed species. The aim of this paper is to describe and formally name such species.

\footnotetext{
${ }^{1}$ Universidade Estadual de Maringá, Núcleo de Pesquisas em Limnologia, Ictiologia e Aquicultura, Avenida Colombo, 5790, 87020-900 Maringá, PR, Brazil. luiztencatt@hotmail.com (LFCT); carlasp@nupelia.uem.br (CSP).

${ }^{2}$ Universidade Federal do Rio de Janeiro, Museu Nacional, Departamento de Vertebrados, Setor de Ictiologia, Quinta da Boa Vista s/n, São Cristóvão, 20940-040 Rio de Janeiro, RJ, Brazil. mrbritto2002@yahoo.com.br
} 


\section{Material and Methods}

Measurements were obtained using digital calipers to the nearest tenth of millimeter. Morphometric and meristic data were taken following Reis (1997), except for the exclusion of the length of the anal-fin spine that is absent in all Corydoradinae. The length of the pectoral-fin spine was included in the morphometric analysis and was taken from its base to its distal tip. Morphometrics are reported as percents of standard length (SL) and head length (HL). Homology of barbels follows Britto \& Lima (2003). Some specimens were cleared and stained (c\&s) according to the protocol of Taylor \& Van Dyke (1985). Osteologic terminology was based on Reis (1998), except for the use of the terms parieto-supraoccipital instead of supraoccipital (Arratia \& Gayet, 1995) and compound pterotic instead of pterotic-supracleithrum (Aquino \& Schaefer, 2002).

Counts of vertebrae followed Britto et al. (2009). In the description, numbers between parenthesis represent the total number of specimens with those counts. Numbers followed by an asterisk refer to the counts of the holotype. Comparative data of Corydoras diphyes were obtained from Axenrot \& Kullander (2003). Institutional abbreviations are: AI, Asociación Ictiológica de La Plata, La Plata; LBP, Laboratório de Biologia de Peixes da Universidade Estadual Paulista "Júlio de Mesquita Filho", Botucatu; DZSJRP, Coleção de Peixes do Departamento de Zoologia e Botânica da Universidade Estadual Paulista "Júlio de Mesquita Filho", São José do Rio Preto; MCP, Museu de Ciências e Tecnologia, Pontifícia Universidade Católica do Rio Grande do Sul, Porto Alegre; MNRJ, Museu Nacional, Universidade Federal do Rio de Janeiro, Rio de Janeiro; MZUSP, Museu de Zoologia da Universidade de São Paulo, São Paulo; NRM, Naturhistoriska Riksmuseet, Department of Vertebrate Zoology, Stockholm; NUP, Coleção Ictiológica do Núcleo de Pesquisas em Limnologia, Ictiologia e Aquicultura da Universidade Estadual de Maringá, Maringá; ZUEC-PIS, Coleção de Peixes do Museu de Zoologia da Universidade Estadual de Campinas, Campinas; ZUFMS-PIS, Coleção Zoológica de Referência da Universidade Federal de Mato Grosso do Sul, Campo Grande.

\section{Results}

\section{Corydoras gryphus, new species} Figs. 1-3

Holotype. MNRJ 40770, 32.3 mm SL, Brazil, Paraná, Foz do Iguaçu, rio Paraná (near Ponte da Amizade), approximately $25^{\circ} 31^{\prime} \mathrm{S} 54^{\circ} 38^{\prime} \mathrm{W}$, 15 Oct 1982, Biology team of the Universidade Estadual de Maringá.

Paratypes. MCP 47852, 6, 23.4-30.4 mm SL; MNRJ 40771, 6, 24.631.9 mm SL; NUP 1572, 21, 21.9-35.0 mm SL; NUP 14676, 3 c\&s,
27.7-32.4 mm SL; ZUEC-PIS 7656, 9, 25.5-31.8 mm SL, collected with the holotype.

Diagnosis. Corydoras gryphus is distinguished from its congeners by a conspicuously reduction on posterior laminar expansion of infraorbital 2, almost absent in some specimens ( $v s$. infraorbital 2 with moderate- or well-developed posterior laminar expansion). The new species differs from its congeners, except $C$. longipinnis and $C$. tukano, by the presence of an uncommon sexual dimorphic condition, with the conspicuous elongation of the first and second branched dorsal-fin rays in males surpassing dorsal-fin spine distal tip, with size similar to the total length of the spine (vs. dorsal fin not sexually dimorphic with respect to its length; or elongation of dorsal-fin elements (when present) not associated with sexual dimorphism; or dorsal fin, if sexually dimorphic, with first and second dorsal-fin branched rays slightly surpassing dorsal-spine distal tip). The new species is also distinguished from C. longipinnis and C. tukano by the presence of four to six irregular black or brownish blotches on the midline of the flank (vs. midline of the flank with three large black rounded blotches in C. longipinnis; two very large black rounded blotches in C. tukano). Corydoras gryphus is further distinguished from C. longipinnis by having the mesethmoid not visible, entirely covered by a thick layer of skin ( $v s$. visible, posterior portion of mesethmoid covered by a very thin epidermal layer). See additional diagnostic features in the discussion.

Description. Morphometric data in Table 1. Head compressed with slightly convex dorsal profile; triangular in dorsal view. Snout slightly pointed. Head profile convex from snout to tip of posterior process of parieto-supraoccipital. Profile slightly convex along dorsal-fin base. Body profile between dorsal fin and adipose-fin spine slightly concave; concave from that point to caudal-fin base. Ventral profile of body nearly straight from isthmus to pectoral girdle; slightly convex from that point to pelvic girdle. Profile nearly straight from pelvic girdle to base of first anal-fin ray; concave from that point to caudal-fin base. Body roughly elliptical in cross section at pectoral girdle, gradually becoming more compressed toward caudal fin.

Eye rounded, located dorso-laterally on head; orbit delimited dorsally by frontal and sphenotic, ventrally by infraorbitals. Anterior and posterior nares close to each other, only separated by flap of skin. Anterior naris tubular. Posterior naris close to anterodorsal margin of orbit, separated from it by distance equal to diameter of naris. Mouth small, subterminal, width nearly equal to bony orbit diameter. Maxillary barbel moderate in size, not reaching anteroventral limit of gill opening. Outer mental barbel slightly longer than maxillary barbel. Inner mental barbel fleshy, with base close to its counterpart. Small rounded papillae covering entire surface of all barbels, upper and lower lips, and isthmus. 


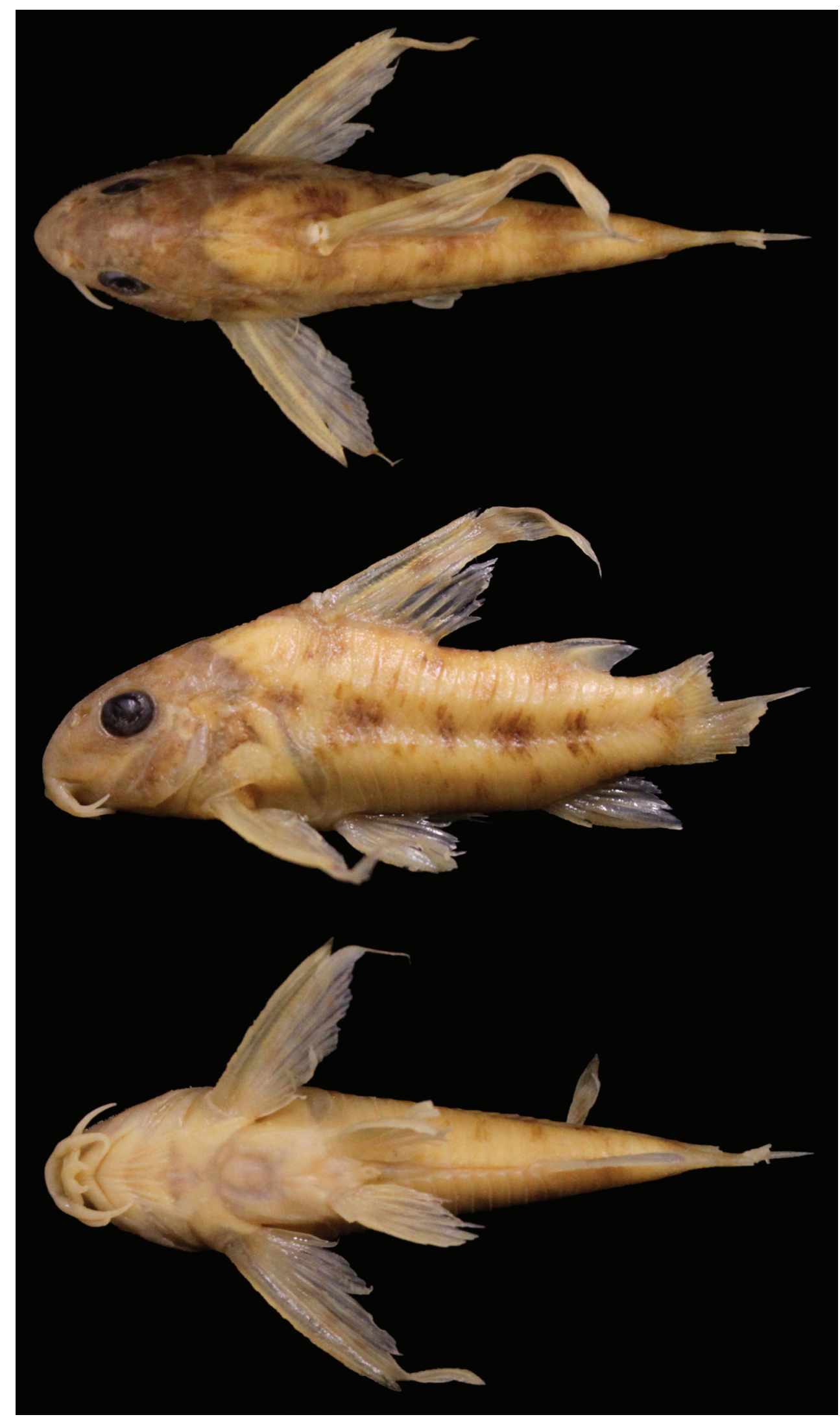

Fig. 1. Corydoras gryphus, holotype, MNRJ 40770, 32.3 mm SL, Brazil, Paraná, Foz do Iguaçu, rio Paraná (near to Ponte

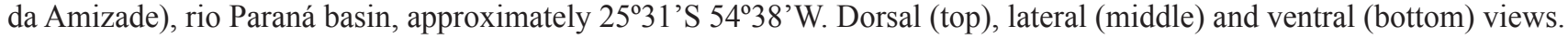


Table 1. Morphometric data of Corydoras gryphus. $\mathrm{N}=20$ specimens and $\mathrm{SD}=$ standard deviation.

\begin{tabular}{|c|c|c|c|}
\hline & Holotype & Low-High & Mean \pm SD \\
\hline Standard length $(\mathrm{mm})$ & 32.3 & $26.2-34.8$ & $29.2 \pm 2.3$ \\
\hline \multicolumn{4}{|l|}{ Percents of standard length } \\
\hline Depth of body & 34.4 & $30.6-35.9$ & $33.1 \pm 1.4$ \\
\hline Predorsal distance & 49.2 & $46.6-50.5$ & $48.6 \pm 1.0$ \\
\hline Prepelvic distance & 47.7 & $44.0-49.2$ & $47.2 \pm 1.6$ \\
\hline Preanal distance & 79.3 & $75.8-81.9$ & $79.5 \pm 1.6$ \\
\hline Preadipose distance & 82.7 & $79.6-86.0$ & $82.6 \pm 1.5$ \\
\hline Length of dorsal spine & 32.8 & $25.2-34.5$ & $29.2 \pm 2.5$ \\
\hline Length of pectoral spine & 35.9 & $26.7-35.9$ & $30.6 \pm 2.3$ \\
\hline Length of adipose-fin spine & 11.8 & $8.1-13.5$ & $10.5 \pm 1.4$ \\
\hline Depth of caudal peduncle & 13.9 & $12.8-14.9$ & $13.9 \pm 0.5$ \\
\hline Length of dorsal-fin base & 18.3 & $14.1-18.3$ & $16.4 \pm 1.0$ \\
\hline Dorsal to adipose distance & 18.6 & $15.7-22.1$ & $18.9 \pm 1.5$ \\
\hline Maximum cleithral width & 26.6 & $25.3-29.5$ & $27.1 \pm 0.9$ \\
\hline Head length & 42.1 & $39.9-48.6$ & $42.8 \pm 1.8$ \\
\hline Length of maxillary barbel & 12.1 & $7.7-14.9$ & $11.4 \pm 1.8$ \\
\hline \multicolumn{4}{|l|}{ Percents of head length } \\
\hline Head depth & 75.0 & $63.0-78.4$ & $72.1 \pm 3.7$ \\
\hline Least interorbital distance & 26.5 & $22.2-26.9$ & $24.8 \pm 1.2$ \\
\hline Horizontal orbit diameter & 25.0 & $20.7-26.3$ & $24.5 \pm 1.3$ \\
\hline Snout length & 34.6 & $29.3-36.6$ & $34.0 \pm 1.6$ \\
\hline Least internarial distance & 9.6 & $7.1-9.8$ & $9.3 \pm 1.4$ \\
\hline
\end{tabular}

Mesethmoid short, totally covered by thin layer of skin. Nasal elongate and slender, smoothly curved laterally, inner margin laminar; mesial border contacting frontal and mesethmoid; with two nasal pores. Frontal elongated, narrow, width less than half entire length; anterior projection short, size smaller than nasal length; epiphysial branch of supraorbital canal short, pore opening mesially on frontal. Frontal fontanel large, oval; posterior tip extension entering anterior margin of parieto-supraoccipital. Parieto-supraoccipital wide, posterior process long and contacting nuchal plate. Two laminar infraorbitals with minute odontodes; infraorbital 1 moderately developed, relatively slender; anterior portion with moderate expansion (Fig. 2a); infraorbital 2 small, conspicuously slender, with posterior laminar expansion very reduced (Fig. 2a), almost imperceptible in some specimens; posteroventral margin contacting supra-preopercle, dorsal tip contacting sphenotic. Interopercle covered by thin layer of skin, somewhat triangular, with anterior projection well developed. Preopercle slender, elongated, with minute odontodes sparse on external surface. Opercle elongated in shape, width nearly equal to, or smaller than half of its length; free margin smooth, without serrations and covered with small odontodes. Anteroventral portion of cleithrum exposed; posterolateral portion of scapulocoracoid exposed;
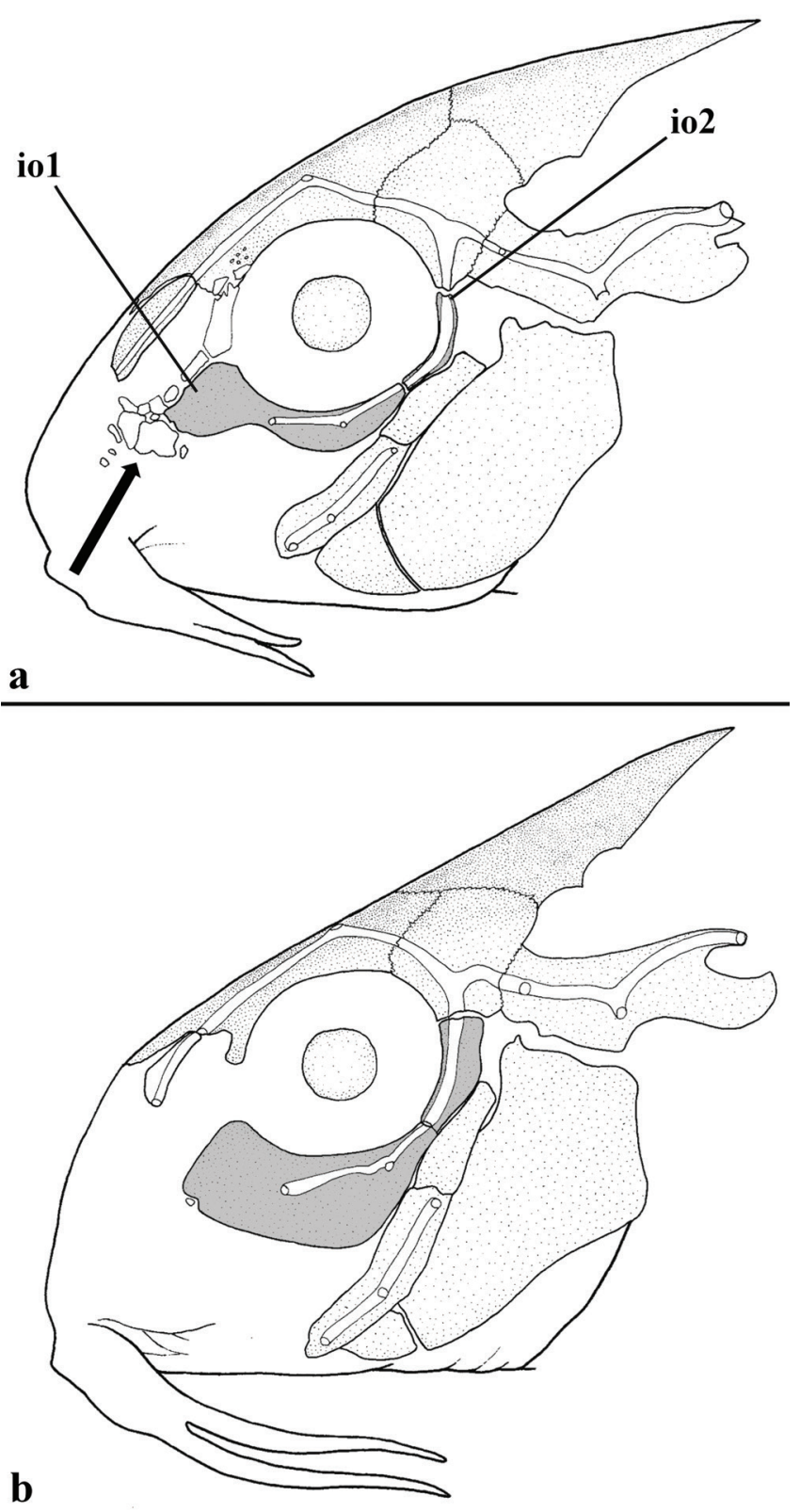

Fig. 2. Schematic drawing of the heads of (a) Corydoras gryphus, paratype, NUP 14676, $32.4 \mathrm{~mm} \mathrm{SL}$, and (b) Corydoras flaveolus, LBP 14596, $33.8 \mathrm{~mm}$ SL, in lateral view, showing the slender infraorbitals 1 and 2 of Corydoras gryphus and the thicker ones of $C$. flaveolus. Infraorbital 1 and 2 highlighted in gray. Arrow indicates the platelets present in lateral portion of snout and anterior margin of orbit, omitted in C. flaveolus. Abbreviations: io1: infraorbital 1, io2: infraorbital 2.

minute odontodes sparse on exposed areas. Vertebral count 23(3); ribs 6(3), first pair conspicuously larger.

Four branchiostegal rays decreasing in size posteriorly. Hypobranchial 2 somewhat triangular, tip ossified and directed towards anterior portion, posterior margin cartilaginous; ossified portion well developed, about twice size of cartilaginous portion. Five ceratobranchials with expansions 


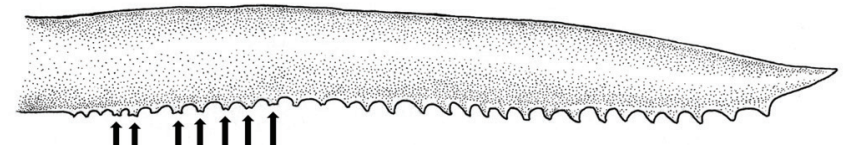

Fig. 3. Pectoral-fin spine of Corydoras gryphus, paratype, NUP 14676, $32.4 \mathrm{~mm} \mathrm{SL}$, showing the serrations on posterior margin of the right spine ( $9.5 \mathrm{~mm}$ long). The arrows indicate the bifid serrations.

increasing posteriorly; ceratobranchial 1 with small process on anterior margin of mesial portion; ceratobranchial 3 notched on postero-lateral margin; ceratobranchial 5 toothed on postero-dorsal surface, 33(1) or 34(2) teeth aligned in one row. Four epibranchials with similar size; epibranchial 2 slightly larger than others, with small pointed process on laminar expansion of posterior margin; epibranchial 3 with uncinate process on laminar expansion of posterior margin. Two wide pharyngobranchials, pharyngobranchial 3 lacking process on posterior margin. Upper tooth plate oval; 33(1) or 39(2) teeth aligned in two rows on postero-ventral surface.

Dorsal fin roughly triangular, located just posterior to second dorsolateral body plate. Dorsal-fin rays II,8(20), posterior margin of dorsal-fin spine with 14 to 25 serrations, disposed along entire length of spine; proximal portion of dorsal spine without serrations in some specimens. Nuchal plate exposed with minute odontodes; spinelet short; dorsalfin spine very long, adpressed distal tip almost reaching or reaching to adipose-fin origin, its posterior margin with small odontodes. Pectoral fin triangular, its origin just posterior to gill opening. Pectoral-fin rays I,7(20); posterior margin of pectoral spine with 23 to 33 moderately developed serrations, disposed generally along entire length of posterior margin; simple and bifid serrations (Fig. 3). Pelvic fin oblong, located just below first ventrolateral body plate, and at vertical through first branched dorsal-fin ray. Pelvic-fin rays i,5(20). Adipose fin roughly triangular, separated from base of last dorsal-fin ray by generally seven dorsolateral body plates. Anal fin triangular, located just posterior to $12^{\text {th }}$ ventrolateral body plates, and at vertical through anterior margin of adipose-fin spine. Anal-fin rays i,6(20). Caudal fin forked. Caudal-fin rays $\mathrm{i}, 12, \mathrm{i}(20)$, generally three dorsal and three ventral procurrent rays; caudal-fin bilobed, lobes similar in size.

Three or four laterosensory canals on trunk; first ossicle tubular, second ossicle laminar, third and fourth canals fused to third and fourth dorsolateral body plates, respectively. Body plates with minute odontodes scattered over exposed area, and conspicuous line of odontodes confined on posterior margins; dorsolateral body plates $23 *(16)$ or $24(4)$; ventrolateral body plates $20(6)$ or $21 *(14)$; dorsolateral body plates along dorsal-fin base 5(6) or $6^{*}(14)$; dorsolateral body plates between adipose and caudal fins $6(3), 7^{*}(16)$ or $8(1)$; preadipose platelets $2(4)$ or $3 *(16)$, adipose spine opposed to anal-fin insertion; small platelets covering base of caudal-fin rays; small platelets disposed dorsally and ventrally between junctions of lateral plates on posterior portion of caudal peduncle. Anterior margin of orbit with platelets, above

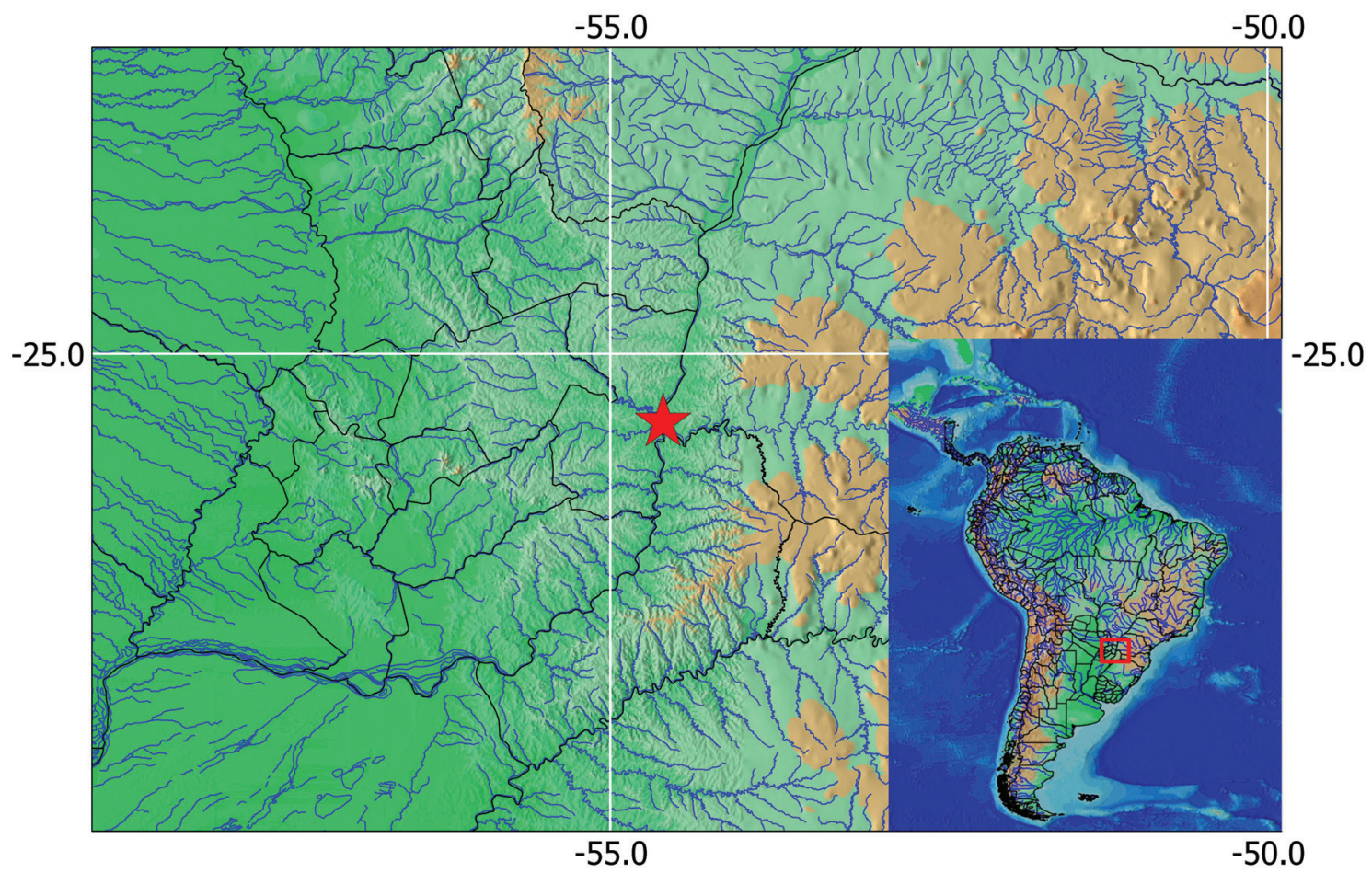

Fig. 4. Map showing the type locality (red star) of Corydoras gryphus, rio Paraná near Itaipu dam, Paraná. 
posterior portion of lateral ethmoid and above junction of frontal and lateral ethmoid; posterior and ventral margins of nasal capsule with platelets. Lateral portion of snout with platelets in some specimens (Fig. 2a). Ventral surface of body with few irregular platelets; platelets absent in some specimens.

Color in alcohol. Ground color of body brownish yellow, with top of head dark brown. Head without spots. Region of nasal bone dark. Opercle with pale border; anterior portion dark brown. Upper portion of dorsolateral plates dark blotched. Dorsal series of four dark brown blotches, first on anterior portion of dorsal-fin base, second on posterior portion of dorsal-fin base, third on adipose-fin base and fourth on caudal-fin base. Midline of flank with four to six irregular black blotches, different in size from each other, generally elongated transversally. Inferior portion of ventrolateral body plates generally dark spotted posteriorly to pelvic fin. Dorsal and pectoral fins scarcely dark mottled. Pelvic fin hyaline. Adipose fin generally with hyaline membrane and with darkened area on distal portion of membrane in some specimens. Middle portion of anal fin with black blotch.
Middle portion of caudal-fin base with small black dot Caudal fin with three or four transverse black bars.

Sexual dimorphism. Corydoras gryphus presents a sexual dimorphism very similar to that described for C. tukano and $C$. longipinnis, with the first and second branched dorsal-fin rays conspicuously elongated in males, almost reaching caudal-fin origin in some specimens. The first branched ray of the pectoral fin is elongated in males. The dorsal- and pectoral-fin spines are well-developed in both sexes but are slightly larger in adult males. Dorsal- and pectoral-fin spines have segmented expansions, similar to those exhibited by Aspidoras Ihering and Scleromystax Günther. Infraorbital 1 has well-developed odontodes in males.

Distribution. Corydoras gryphus is known from its type locality, the lower rio Paraná, near Itaipu dam (Fig. 4).

Etymology. From the Latin, the specific name gryphus means griffon, mythical creature with a lion body and a head and wings of a hawk or eagle, in allusion to the conspicuous elongation of pectoral-fin spine and its first branched ray, like a wing in male specimens. A noun in apposition.

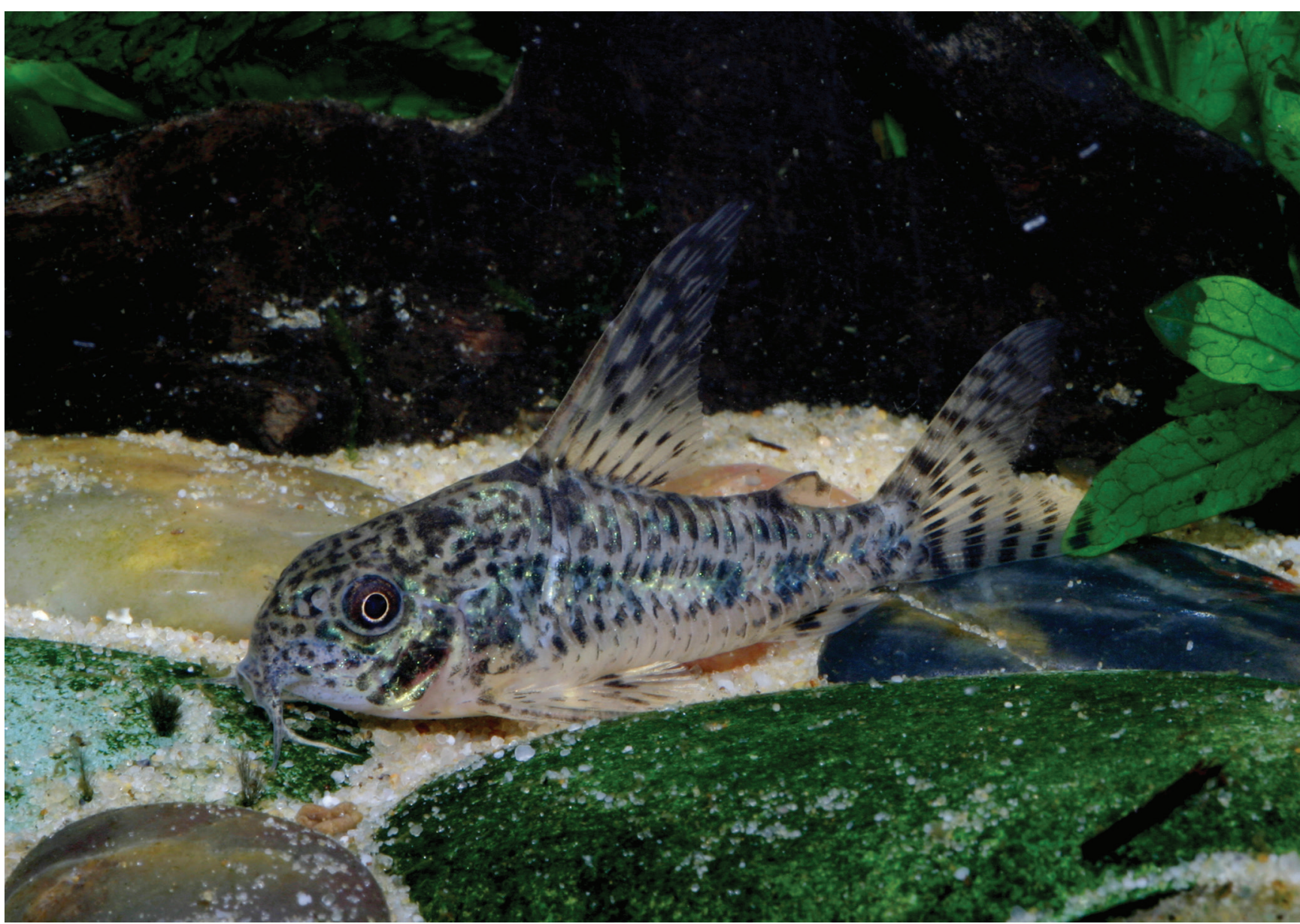

Fig. 5. Photograph showing an aquarium specimen of Corydoras sp. 'Misiones' with $35.0 \mathrm{~mm}$ SL. Photo by Ian Fuller. 
Remarks. Fuller \& Evers (2011: 64-65) mentioned the presence of an undescribed species from the Misiones Province, Argentina (Fig. 5). The presence of irregular and slightly vertically elongated small black blotches along midline of the flank is shared between the new species and Corydoras sp. 'Misiones' (see Figs. 1, 5). On the other hand, Corydoras sp. 'Misiones' present irregular and striated black spots on the snout and dorsal portion of the head, which are absent in C. gryphus. However, Corydoras sp. 'Misiones' present the same unusual sexual dimorphism of C. gryphus, C. longipinnis and C. tukano. Additionally, through the analysis of high-definition photographs, it was possible to observe that Corydoras sp. 'Misiones' also presents a reduced laminar expansion of infraorbital 2 and relatively slender infraorbital 1, similar to C. gryphus condition. Furthermore, the type locality of C. gryphus is relatively near to the territory of Misiones Province. Despite the similarity between the new species and Corydoras sp. 'Misiones', the precise confirmation that they are the same species can only be made through the analysis of preserved specimens of Corydoras sp. 'Misiones'.

\section{Discussion}

The conspicuous slender infraorbital 2 with a very reduced posterior laminar expansion was not observed in any examined specimens from other species of Corydoras. Corydoras gryphus has this bone generally almost reduced to a canal whereas the remaining species have a relatively thicker (Fig. 2b) or very thick (see Tencatt et al., 2013: fig. 2c) infraorbital 2 bone due to the more developed posterior laminar expansions. Other interesting feature observed in the new species is the absence of the process in the pharyngobranchial 3 , which is rounded or triangular in other species. However, the examined material of Corydoras gryphus is old and the c\&s material is somewhat damaged which hampered the osteological analysis. Despite that, in all the examined material the process in pharyngobranchial 3 is absent, which suggests that this species, in fact, lacks this feature.

The presence of segmented expansions in dorsal and pectoral spines and the conspicuous prolongation of the first and second branched rays of dorsal fin are frequently observed in males of species of Scleromystax. Among species of Corydoras, this is unusual and has been observed only in C. longipinnis and C. tukano. However, Corydoras gryphus can be clearly distinguished from those species by having four to six relatively large irregular black blotches along midline of flank ( $v s$. three large rounded black blotches on midline of flank in C. longipinnis; two very large black rounded blotches in C. tukano). The female specimens of Corydoras gryphus also exhibit a relatively large dorsal-fin spine, surpassing the base of the last branched ray of dorsal fin when adpressed, contrary to $C$. longipinnis and $C$. tukano females, which present dorsal spine not surpassing the origin of the last branched ray of dorsal fin. Despite elongation in dorsal-fin elements in other Corydoras species, no evidence correlates it with sexual dimorphism, as mentioned by Britto \& Lima (2003: 89). Accordingly, the condition found in C. gryphus, C. longipinnis, and C. tukano is treated herein as distinct from that observed in the remaining species of Corydoras.

A revisionary study about Corydoras paleatus species complex conducted by the first author (Tencatt, 2013) indicates that Corydoras paleatus presents no sexually-dimorphic characters as reported to C. gryphus, C. longipinnis and C. tukano. Thus, long dorsal-finned specimens assigned as Corydoras paleatus are in fact misidentifications.

Among Corydoras species from the rio Paraná basin, Corydoras diphyes and C. flaveolus are the species that exhibit the most similar color pattern to Corydoras gryphus. However, the new species can be distinguished from both species by lacking dark spots on the head (vs. spots present on the dorsal portion of head and snout) and by having irregular and variable-in-size black blotches on midline of flank ( $v s$. rounded blotches with similar size). Corydoras gryphus also presents pectoral and anal fins with black bars, whereas these fins are hyaline in $C$. diphyes. The new species also differs from $C$. diphyes by having the posterior margin of pectoral-fin spine with serrations along its entire length ( $v s$. serrations only on distal half of the spine), a larger head (39.9-48.6\% vs. 29.2$33.8 \%$ of SL), a shorter snout (29.3-36.6\% vs. $48.5-56.0 \%$ of $\mathrm{HL}$ ), conspicuous sexual dimorphism ( $v s$. indistinct sexually dimorphic features), and by a higher number of vertebrae (22 excluding the Weberian complex, which are not reported in Axenrot \& Kullander (2003), vs. 18 or 19).

The rio Paraná is the second longest river of South America, being the main tributary to the Río de La Plata (Agostinho \& Júlio-Júnior, 1999). The continuous damming processes have caused many changes in its main channel (Graça \& Pavanelli, 2007). The previous natural barrier between the two different ichthyofaunistic provinces of the rio Paraná basin is currently the Itaipu dam (Bonetto, 1986; Agostinho \& Júlio-Júnior, 1999). However, after the conclusion of the "Canal da Piracema" at the end of 2002, the segregation of the ichthyofauna between lower and upper rio Paraná basins are not more effective, allowing circulation of some species through the different regions of the basin (Makrakis et al., 2007). Specimens of the new species were collected in the rio Paraná basin, just downstream from the Itaipu dam. Despite it had never been recorded in the floodplain of the upper rio Paraná hitherto, its occurrence is presumable there, mostly due to the Canal da Piracema.

Comparative Material. All lots of the comparative material available in Britto (2003) were analyzed. In addition, the following 
specimens were examined: Corydoras longipinnis. Argentina. Santiago del Estero: AI 221, holotype, $59.5 \mathrm{~mm} \mathrm{SL}$, río Sali, San Miguel de Tucumán. NUP 14439, 2, 28.6-32.4 mm SL, arroyo Los Perez. NUP 14440, 2 c\&s, 29.9-33.4 mm SL, arroyo Pampa-Mayo. Corydoras areio. Brazil. Mato Grosso. MNRJ 20694, 2, 27.0-41.5 mm SL, rio Parnaíba. NUP 10227, 1, 17.6 mm SL, córrego Cancela. Mato Grosso do Sul. ZUFMS-PIS 1105, 5, 33.7-44.4 mm SL, unnamed stream. ZUFMS-PIS 1314, 17, 34.4-41.9 mm SL, córrego São João. Corydoras britskii. Brazil. Mato Grosso do Sul. ZUFMSPIS 862, 12, 72.0-78.0 mm SL, marginal lagoon to rio Vermelho. Corydoras carlae. Brazil. Paraná. NUP 711, 1, 47.9 mm SL, rio Tormenta. NUP 4425, 1 c\&s, 45.0 mm SL, rio Tormenta. NUP 4868, 2, 44.7-46.6 mm SL, rio Adelaide. NUP 4870, 2, 51.1-53.5 mm SL, rio Adelaide. NUP 4871, 1, $50.4 \mathrm{~mm} \mathrm{SL}$, rio Adelaide. NUP 4872, 1, $46.1 \mathrm{~mm} \mathrm{SL}$, rio Adelaide. NUP 4874, 1, $48.8 \mathrm{~mm} \mathrm{SL}$, rio Tormenta. NUP 4875, 3, 43.8-50.1 mm SL, rio Tormenta. NUP 4877, 3, 44.1-50.6 mm SL, rio Tormenta. NUP 4878, 1, $51.5 \mathrm{~mm}$ SL, rio Tormenta. NUP 4880, 1, $30.2 \mathrm{~mm}$ SL, rio Guarani. NUP 4897 , 1, $51.0 \mathrm{~mm}$ SL, rio Tormenta. Corydoras cochui. Brazil. Goiás. MZUSP 89055, 6, 18.7-23.6 mm SL, rio do Peixe II. Corydoras difluviatilis. Brazil. Minas Gerais. MCP 16994, 23, 25.7-41.6 mm SL, 2 c\&s, 37.9 and $39.1 \mathrm{~mm}$ SL, stream $45 \mathrm{~km}$ south from Montes Claros along road BR-125 towards Bocaiúva. NUP 9966, 27, 28.4-34.3 mm SL, rio Guarda-Mor. Goiás. MCP 28500, 29, 22.0-45.1 mm SL, 2 c\&s, 24.9 and $45.1 \mathrm{~mm}$ SL, córrego Grande. NUP 1105, 37, 16.0-36.8 mm SL, Corumbá reservoir. Corydoras ehrhardti. Brazil. Paraná. NUP 11255, 15, 36.5-46.8 mm SL, rio São Pedro. Corydoras ellisae. Brazil. Mato Grosso. NUP 3239, 42, 21.0-47.8 mm SL, córrego Forquilha. Corydoras flaveolus. Brazil. São Paulo. DZSJRP 7932, 4, 13.9-31.6 mm SL, córrego do Anzol. DZSJRP 8448, 7, 23.5-32.3 mm SL, córrego da Lapa. LBP 2862, 29, 21.6-38.2 mm SL, rio Alambari. LBP, 13, 25.8-32.9 mm SL, rio Passa-Cinco. LBP 14596, 12, 31.2-37.1 mm SL, 3 c\&s, 33.2-33.8 mm SL, rio Capivara. MNRJ 21538, 3, 28.7-35.9 mm SL, córrego do Óleo. MZUSP 47925, 15 of 22, 33.0-35.1 mm SL, rio Baurú. NUP 84, 2, 25.6-30.0 mm SL, rio Alambari. Corydoras garbei. Brazil. Bahia. MCP 16993, 27, 25.3-37.2 mm SL, 3 c\&s, 27.6-31.9 mm SL, rio Pau de Colher. Minas Gerais. MCP 16942, 28, 24.0-34.8 mm SL, unnamed stream. MNRJ 18089, 16, 20.1-27.4 mm SL, lagoa Perta-Pé. Corydoras hastatus. Brazil. Mato Grosso. NUP 6862, 116, 13.1-20.7 mm SL, baía Caiçara. Corydoras maculifer. Brazil. Tocantins. NUP 8970, 2, 42.0-46.0 mm SL, ribeirão Xambioazinho. Corydoras multimaculatus. Brazil. Minas Gerais. MCP 29025, 2, 20.1-25.4 mm SL, rio Peruaçu. Corydoras pantanalensis. Brazil. Mato Grosso do Sul. NUP 12593, 21, 38.7-51.2 mm SL, tributary to rio Miranda. Corydoras splendens. Brazil. Goiás. NUP 12990 , 1, $43.7 \mathrm{~mm}$ SL, Goiás, tributary to rio Araguaia. Corydoras steindachneri. Brazil. MCP 16597, 2, 32.2-37.9 mm SL, Santa Catarina, stream at Mude-Baixa. Corydoras stenocephalus. Brazil. Amazonas. MNRJ 3625, 3, 31.2-62.3 mm SL, rio Javari. Corydoras tukano. Brazil. Amazonas. MNRJ 25355, 2, paratypes, 24.4-32.0 mm SL, igarapé Cabari. MZUSP 64096, 4, paratypes, 28.2-38.0 mm SL, rio Tiquié. MZUSP 65689, 2, paratypes, 33.2-38.5 mm SL, rio Tiquié. MZUSP 81153, 9, paratypes, 35.4-37.2 mm SL, 6 c\&s, 20.9-38.3 mm SL, rio Tiquié. MZUSP 81179, 2, paratypes, 34.0-36.1 mm SL, rio Tiquié. MZUSP 81194, 5, paratypes, 34.5$40.3 \mathrm{~mm}$ SL, rio Tiquié. MZUSP 81216, 2, paratypes, 17.1-21.3 mm SL, rio Tiquié. MZUSP 81244, 16, paratypes, 20.3-41.4 mm SL, igarapé Cabari. MZUSP 82100, holotype, $40.9 \mathrm{~mm} \mathrm{SL}$, rio Tiquié. Corydoras acutus. Peru. MNRJ 3985, 2, 47.1-54.8 mm SL, Sancho-caño. Corydoras paleatus. Uruguay. Canelones. NRM 39305, 1, $53.9 \mathrm{~mm}$ SL, and NRM 39325, 1, $40.5 \mathrm{~mm}$ SL, arroyo Pando. NRM 54230, 1, 53.5 mm SL, arroyo Sarandí.

\section{Acknowledgments}

We thank Jorge Casciotta and Adriana Almirón (AI), Claudio Oliveira (LBP), Francisco Langeani (DZSJRP), Carlos and Margarete Lucena (MCP), Paulo Buckup (MNRJ), Mário de Pinna and Osvaldo Oyakawa (MZUSP), Sven Kullander (NRM), Flávio Lima (ZUEC-PIS) and Otávio Froehlich (ZUFMS-PIS) for the loan of specimens and information about material, and other assistance during visits to their institutions. Thanks to Ian Fuller who kindly provided photographs of live specimens and information of Corydoras sp. 'Misiones'. The Núcleo de Pesquisas em Limnologia, Ictiologia e Aquicultura (Nupélia) of the Universidade Estadual de Maringá provided logistical support. The authors are grateful to Gabriel Deprá for kindly making the drawings. The Coordenação de Aperfeiçoamento de Pessoal de Nível Superior (CAPES) provided fellowships to LFCT and the Conselho Nacional de Desenvolvimento Científico e Tecnológico (CNPq) provided grants to CSP. MRB and CSP are members of the US National Science Foundation project entitled Planetary Biodiversity Inventory: All Catfish Species Inventory (ACSI).

\section{Literature Cited}

Agostinho, A. A. \& H. F. Júlio Jr. 1999. Peixes da bacia do alto rio Paraná. Pp. 374-400. In: Lowe-McConnell, R. H. (Ed.). Estudos ecológicos de peixes tropicais (translation). São Paulo, Edusp.

Alexandrou, M. A., C. Oliveira, M. Maillard, R. A. R. McGuill, J. Newton, S. Creer \& M. I. Taylor. 2011. Competition and phylogeny determine community structure in Müllerian co-mimics. Nature, 469: 84-88.

Aquino, A. E. \& S. A. Schaefer. 2002. The temporal region of the cranium of loricarioid catfishes (Teleostei: Siluriformes): morphological diversity and phylogenetic significance. Zoologischer Anzeiger, 241: 223-244.

Arratia, G. \& M. Gayet. 1995. Sensory canals and related bones of Tertiary siluriform crania from Bolivia and North America and comparison with recent forms. Journal of Vertebrate Paleontology, 15: 482-505.

Axenrot, T. E. \& S. O. Kullander. 2003. Corydoras diphyes (Siluriformes: Callichthyidae) and Otocinclus mimulus (Siluriformes: Loricariidae), two new species of catfishes 
from Paraguay, a case of mimetic association. Ichthyological Exploration of Freshwaters, 14: 249-272.

Bonetto, A. A. 1986. The Paraná river system. Pp. 541-555. In: Davies, B. R. \& K. F. Walker (Eds.). The ecology of river systems. Dordrecht, Dr. W. Junk Publishers.

Britto, M. R. 2003. Phylogeny of the subfamily Corydoradinae Hoedeman, 1952 (Siluriformes: Callichthyidae), with a definition of its genera. Proceedings of the Academy of Natural Sciences of Philadelphia, 153: 119-154.

Britto, M. R. \& F. C. T. Lima. 2003. Corydoras tukano, a new species of corydoradine catfish from the rio Tiquié, upper rio Negro basin, Brazil (Ostariophysi: Siluriformes: Callichthyidae). Neotropical Ichthyology, 1: 83-92.

Britto, M. R., W. B. Wosiacki \& L. F. A. Montag. 2009. A new species of Corydoradinae catfish (Ostariophysi: Siluriformes: Callichthyidae) from Rio Solimões Basin, Brazil. Copeia, 2009: 684-689.

Eschmeyer, W. N. 2013. Catalog of Fishes, California Academy of Sciences, San Francisco. Available from: http://research. calacademy.org/ichthyology/catalog (25 April 2013).

Fuller, I. A. \& H. G. Evers. 2011. Identifying Corydoradinae Catfish: Aspidoras, Brochis, Corydoras, Scleromystax, C-numbers \& CWnumbers: Supplement 1. Worcestershire, Ian Fuller Enterprises.

Gosline, W. A. 1940. A revision of the Neotropical catfishes of the family Callichthyidae. Stanford Ichthyological Bulletin, 2: 1-29.

Graça, W. J. \& C. S. Pavanelli. 2007. Peixes da planície de inundação do alto rio Paraná e áreas adjacentes. Maringá, Eduem.

Makrakis, S., L. C. Gomes, M. C. Makrakis, D. R. Fernandez \& C. S. Pavanelli. 2007. The Canal da Piracema at Itaipu Dam as a fish pass system. Neotropical Ichthyology, 5: 185-195.

Nijssen, H. 1970. Revision of the Surinam catfishes of the genus Corydoras Lacépède, 1803 (Pisces, Siluriformes, Callichthyidae). Beaufortia, 18: 1-75.
Nijssen, H. \& I. J. H. Isbrücker. 1980. A review of the genus Corydoras Lacépède, 1803 (Pisces, Siluriformes, Callichthyidae). Bijdrague Dierkunde, 50: 190-220.

Reis, R. E. 1997. Revision of the Neotropical genus Hoplosternum (Ostariophysi: Siluriformes: Callichthyidae) with the description of two new genera and three new species. Ichthyological Exploration of Freshwaters, 7: 299-326.

Reis, R. E. 1998. Anatomy and phylogenetic analysis of the neotropical callichthyid catfishes (Ostariophysi, Siluriformes). Zoological Journal of the Linnean Society, 124: 105-168.

Reis, R. E. 2003. Family Callichthyidae (armored catfishes). Pp. 291-309. In: Reis, R. E., S. O. Kullander \& C. J. Ferraris, Jr. (Eds.). Check List of the Freshwater Fishes of South and Central America. Porto Alegre, Edipucrs.

Taylor, W. R. \& G. C. Van Dyke. 1985. Revised procedures for staining and clearing small fishes and other vertebrates for bone and cartilage study. Cybium, 9: 107-119.

Tencatt, L. F. C. 2013. Redescrição de Corydoras paleatus (Jenyns, 1842) (Siluriformes: Callichthyidae) com a descrição de quatro novas espécies. Unpublished M.Sc. Dissertation, Universidade Estadual de Maringá, Maringá, 60p.

Tencatt, L. F. C., H. S. Vera-Alcaraz, M. R. Britto \& C. S. Pavanelli. 2013. A new Corydoras Lacépède, 1803 (Siluriformes: Callichthyidae) from the rio São Francisco basin, Brazil. Neotropical Ichthyology, 11: 257-264.

Submitted July 27, 2013

Accepted November 18, 2013 by Paulo Lucinda

Published March 31, 2014 